\title{
ESTIMATION OF IONS CONCENTRATION IN AQUEOUS SULFURIC ACID MIXTURES BY RESOLUTION OF RAMAN SPECTRA
}

\author{
(Presented by 0. Eisen)
}

The ionic composition of aqueous sulfuric acid solutions has mostly been studied by Raman spectroscopy $\left[{ }^{1-3}\right]$. The majority of researchers have accepted the respective results obtained by $\mathrm{H}$. Chen and D. E. Irish [ $\left.{ }^{1}\right]$. The concentration profiles of $\mathrm{SO}_{4}^{2-}$ and $\mathrm{HSO}_{4}^{-}$presented in ['] have been used for the calculation of the hydrated proton concentration $\left[{ }^{4}\right]$ $\left(C_{\mathrm{H}^{+}}+=C_{\mathrm{HSO}_{4}^{-}}+2 C_{\mathrm{SO}_{4}^{2-}}\right)$. The last quantity $\left(C_{\mathrm{H}^{+}}\right)$, in turn, plays an important role in determining weak bases basicity constants by the excess acidity method [4]. It should be noted that $\mathrm{H}$. Chen and D. E. Irish [ $\left.{ }^{1}\right]$ discussed the existence of ion pairs $\mathrm{H}_{3} \mathrm{O}^{+} \cdot \mathrm{SO}_{4}^{2-}$ and $\mathrm{H}_{3} \mathrm{O}^{+} \cdot \mathrm{HSO}_{4}^{-}$, but no attempt was made to estimate their concentrations separately from those of the respective nonionpaired species. In recent years, some evidence has been accumulated showing that in the system $\mathrm{H}_{2} \mathrm{SO}_{4}-\mathrm{H}_{2} \mathrm{O}$ both ions, $\mathrm{SO}_{4}^{2-}$ and $\mathrm{HSO}_{4}^{-}$, may exist as free ions and as ion pairs $[2,3,5,6,7]$. The structure of the latter has been discussed by several authors $\left[{ }^{5-7}\right]$. In the present paper free ions are denoted as $\mathrm{HSO}_{4} A Q, \mathrm{SO}_{4} A Q$ and ionpaired ones as $\mathrm{HSO}_{4} I P, \mathrm{SO}_{4} I P$, respectively.

H. Chen and D. E. Irish [ $\left.{ }^{1}\right]$ measured the Raman spectra of aqueous sulfuric acid solutions in the range of $2.52-80.58 \% \mathrm{H}_{2} \mathrm{SO}_{4}(\mathrm{w} / \mathrm{w})$. In the paper of R. A. Cox et al. [5] the same was done in a wider range, viz. $4.53-99.48 \% \mathrm{H}_{2} \mathrm{SO}_{4}(\mathrm{w} / \mathrm{w})$. The mathematical treatment of these spectra [5] was carried out using factor analysis (FA) techniques. Two FA methods have been applied to these spectra [5]: the principal component analysis (PCA) $\left.{ }^{8}\right]$ and a novel approach - the spectral isolation analysis (SIA) $\left.{ }^{9}\right]$. The application of FA methods has led to a conclusion that the Raman spectra studied may be presented as a sum of three spectral components which may most likely be assigned to the following sums of species $\left(\mathrm{SO}_{4} A Q+\mathrm{HSO}_{4} A Q\right),\left(\mathrm{SO}_{4} I P+\mathrm{HSO}_{4} I P\right)$ and $\left(\mathrm{H}_{2} \mathrm{SO}_{4}\right)\left[{ }^{5,6}\right.$. The latter is the undissociated sulfuric acid detected in concentrated $\mathrm{H}_{2} \mathrm{SO}_{4}$ solutions. The individual concentration profiles for the species involved were not obtained by the FA methods applied $\left[{ }^{5,6}\right]$. Nevertheless, PCA [ $\left.{ }^{8}\right]$ followed by the curve-fitting procedures yielded the number of individual but overlapping bands in the spectra studied [5]. Altogether 18 spectral bands were resolved out and their maximum locations determined [5]. This information has been used in the present study in order to obtain concentration profiles for the species present in aqueous sulfuric acid solutions.

\section{Raman spectra and their resolution into bands}

The set of spectra used was the same as in [ ${ }^{5,6}$. It consists of 25 Raman spectra covering the range of $4.53-96.71 \% \mathrm{H}_{2} \mathrm{SO}_{4}(\mathrm{w} / \mathrm{w})$. The experimental part has been published elsewhere [5]. The intensities of spectra 


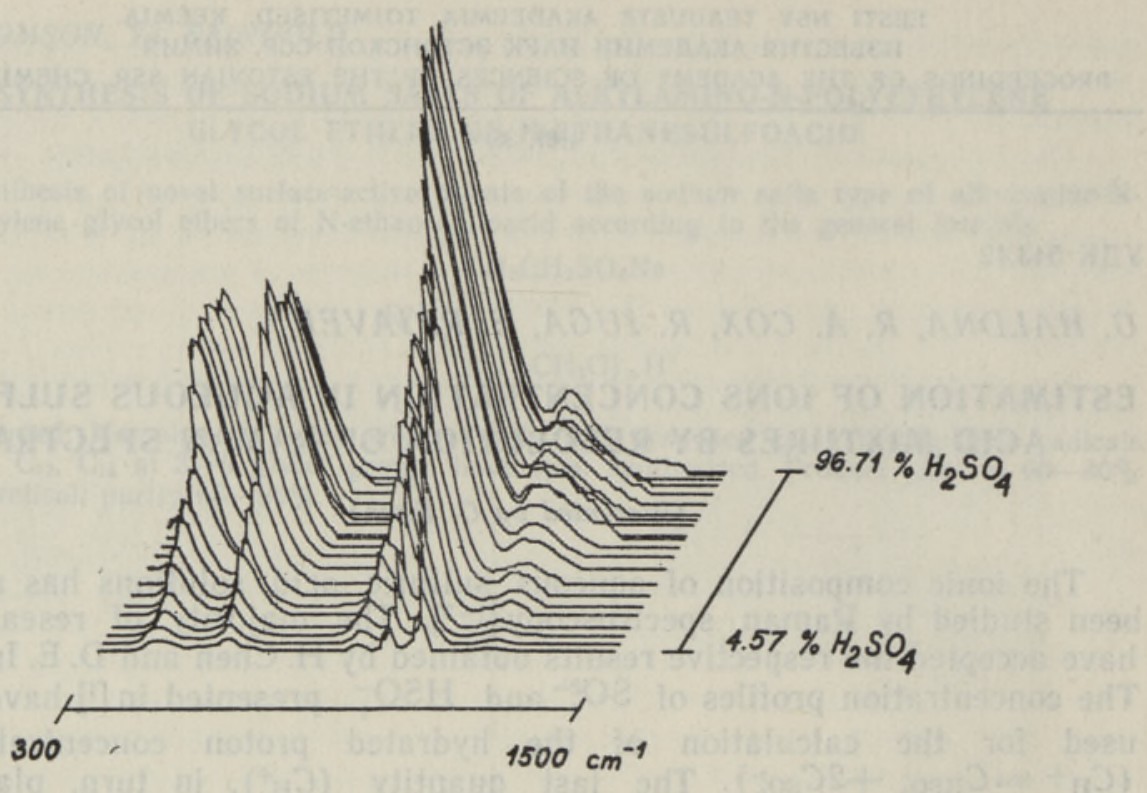

Fig. 1. Standardized Raman spectra of water sulfuric acid mixtures.

were corrected for laser power and signal amplification taking the spectrum of a standard solution (in our case $36.74 \% \quad \mathrm{H}_{2} \mathrm{SO}_{4} \mathrm{w} / \mathrm{w}$ ) before and after each spectrum studied $\left[{ }^{10}\right]$. A factor $(H)$ equal to the mean intensity of the standard solution at $1035 \mathrm{~cm}^{-1}$ taken before and after the spectrum studied was calculated. The standardized intensities $I(v)$ of the spectra studied were obtained according to the equation $\left[{ }^{10,11}\right]$

$$
I(v)=I(v)_{o b s} /\left[H \cdot\left(v-v_{1}\right)^{4}\right],
$$

where $v$ is the wavenumber $\left(\mathrm{cm}^{-1}\right)$ for the observed intensity $I(v)_{\text {obs }}$ and $v_{1}$ is the wavenumber of the laser line used $\left(20485 \mathrm{~cm}^{-1}\right.$ in our case corresponding to the $488 \mathrm{~nm}$ line of the argon ion laser). The spectra in analog form were digitalized by hand taking the intensity readings in $10 \mathrm{~cm}^{-1}$ steps along the $v$-axis. Each recorded band on spectra has been described by $10-15$ points $\left(10 \mathrm{~cm}^{-1}\right.$ apart from each other). This seems to be sufficient for fixing the bands shape unambiguously. The intensity readings were taken from the baseline constructed by hand using "empty" spectral regions. The intensities were digitalized in the range of $300-1500 \mathrm{~cm}^{-1}$ at the same wavenumbers on each spectrum. In this way a spectral data array of $25 \times 120$ points was obtained. Fig. 1 shows the standardized spectra. The relative intensities $I(v)_{\text {obs }} / H$ for the maximum at $1030-1050 \mathrm{~cm}^{-1}$ are presented in Table 1. Each spectrum was curvefitted as a sum of Voigt profiles [12, 13] which are Gaussian-Lorenzian convolutions. Following S. Ikawa and M. Kimura ${ }^{\left[{ }^{12}\right]}$ we have used Kielkopf's approximation to the Voigt profile $\left[{ }^{14}\right]$ with the additional assumption that the Gaussian part of the profile comes only from the finite slit width, $5 \mathrm{~cm}^{-1}$ in our case, i. e. each peak has a Gaussian half-width $\left[{ }^{5},{ }^{13}\right]$ of $3.0 \mathrm{~cm}^{-1}$. Consequently, each Raman band can be specified by one fixed $\left(\beta_{\mathrm{G}}\right)$ and three adjustable $\left(h, \beta_{\mathrm{L}}, v_{\max }\right)$ parameters ( $h$ is the intensity of the band at its maximum $v_{\max }$ and $\beta_{\mathrm{G}}, \beta_{\mathrm{L}}^{\prime}$ are half-widths for the Gaussian and Lorenzian part, respectively). The values of $v_{\max }$ from [5] (see Table 2) were used in the iteration procedures as zero approximations. Two bands out of the 18 resolved out in [5] were not used by us (viz. those at $729 \mathrm{~cm}^{-1}$ assigned to $\mathrm{H}_{2} \mathrm{SO}_{4}$, because it is too weak [5,6], and a band 
Relative intensity of the maximum at $1030-1050 \mathrm{~cm}^{-1}$

\begin{tabular}{c|c|c|c}
\hline$\% \mathrm{H}_{2} \mathrm{SO}_{4}$ & $I_{\text {obs }}(v) / H$ & $\% \mathrm{H}_{2} \mathrm{SO}_{4}$ & $I_{\text {obs }}(v) / H$ \\
\hline & 15 & 65.26 & 152 \\
8.57 & 26 & 67.72 & 155 \\
11.78 & 41 & 69.96 & 158 \\
15.86 & 52 & 75.05 & 162 \\
21.90 & 70 & 80.10 & 159 \\
23.86 & 80 & 84.26 & 149 \\
31.19 & 89 & 87.42 & 136 \\
36.74 & 101 & 89.58 & 125 \\
44.02 & 112 & 90.63 & 114 \\
50.03 & 128 & 92.09 & 105 \\
54.40 & 136 & 94.29 & 99 \\
58.49 & 142 & 96.71 &
\end{tabular}

at $590 \mathrm{~cm}^{-1}$ assigned to $\mathrm{HSO}_{4} I P$ as it is too close to the band at $595 \mathrm{~cm}^{-1}$ ). As a result, at $595 \mathrm{~cm}^{-1}$ a complex band was resolved out and assigned to $\mathrm{SO}_{4} A Q, \mathrm{HSO}_{4} A Q, \mathrm{HSO}_{4} I P\left[{ }^{5}\right]$. This band as well as those at 433 and $1200 \mathrm{~cm}^{-1}$ were further not used to calculate species concentration due to their complex assignments (see Table 2).

Table 2

The spectral bands used in curve-fitting procedures

\begin{tabular}{|c|c|c|c|}
\hline $\mathrm{N}$ & $v_{\max }$ & Assignmen & $A^{*}{ }_{\max }$ \\
\hline 1 & 1361 & $\mathrm{H}_{2} \mathrm{SO}_{4}$ & 1.8 \\
\hline 2 & 1200 & $\mathrm{H}_{2} \mathrm{SO}_{4}, \mathrm{HSO}_{4} A Q, \mathrm{HSO}_{4} I P$ & 12.6 \\
\hline 3 & 1147 & $\mathrm{H}_{2} \mathrm{SO}_{4}$ & 25.6 \\
\hline 4 & 1103 & $\begin{array}{l}\mathrm{SO}_{4} A Q \\
\mathrm{HSO} A O\end{array}$ & 0.3 \\
\hline 5 & $\begin{array}{l}1055 \\
1037\end{array}$ & $\begin{array}{l}\mathrm{HSO}_{4} A Q \\
\mathrm{HSO} I P\end{array}$ & 8.8 \\
\hline $\begin{array}{l}6 \\
7\end{array}$ & $\begin{array}{r}1037 \\
987\end{array}$ & $\mathrm{SO}_{4} A Q$ & $\begin{array}{l}38.8 \\
12.7\end{array}$ \\
\hline 8 & 935 & $\mathrm{SO}_{4} I P$ & 3.0 \\
\hline 9 & 918 & $\mathrm{H}_{2} \mathrm{SO}_{4}$ & 15.2 \\
\hline 10 & 899 & $\mathrm{HSO}_{4} \mathrm{IP}^{2}$ & 20.0 \\
\hline $\begin{array}{l}11 \\
12\end{array}$ & $\begin{array}{l}877 \\
595\end{array}$ & $\begin{array}{l}\mathrm{HSO}_{4} A Q \\
\mathrm{SO}_{4} A Q, \mathrm{HSO}_{4} A Q, \mathrm{HSO}_{4} I P\end{array}$ & $\begin{array}{r}1.3 \\
17.2\end{array}$ \\
\hline 13 & 563 & $\mathrm{H}_{2} \mathrm{SO}_{4}$ & 27.2 \\
\hline 14 & 433 & $\mathrm{H}_{2} \mathrm{SO}_{4}, \mathrm{SO}_{4} A Q, \mathrm{HSO}_{4} A Q$ & 19.8 \\
\hline $\begin{array}{l}15 \\
16\end{array}$ & $\begin{array}{l}417 \\
395\end{array}$ & $\begin{array}{l}\mathrm{HSO}_{4} P \\
\mathrm{H}_{2} \mathrm{SO}_{4}\end{array}$ & $\begin{array}{l}4.7 \\
2.4\end{array}$ \\
\hline
\end{tabular}

* Max. values of area in relative but comparable between themselves units.

A program in FORTRAN IV including the standard least-squares curve-fitting subroutine $\left[{ }^{15}\right]$ was written which yields optimum values for $\beta_{\mathrm{L}}, v_{\max }$ and $h$. Computations were performed on an EC 1052 computer, Institute of Cybernetics, Estonian SSR Academy of Sciences. It should be noted that there exists an "empty" spectral region between $700-800 \mathrm{~cm}^{-1}$. This was used to carry out the curve-fitting procedures for the bands $v_{\max }>800 \mathrm{~cm}^{-1}$ and $v_{\max }<700 \mathrm{~cm}^{-1}$ separately. In the range of $1500-$ $800 \mathrm{~cm}^{-1} 11$ bands (the respective maxima at 1361, 1200, 1147, 1103, 1055, 1037, 987, 935, 918,899, $877 \mathrm{~cm}^{-1}$ ) and in the range of $700-300 \mathrm{~cm}^{-1}$ 


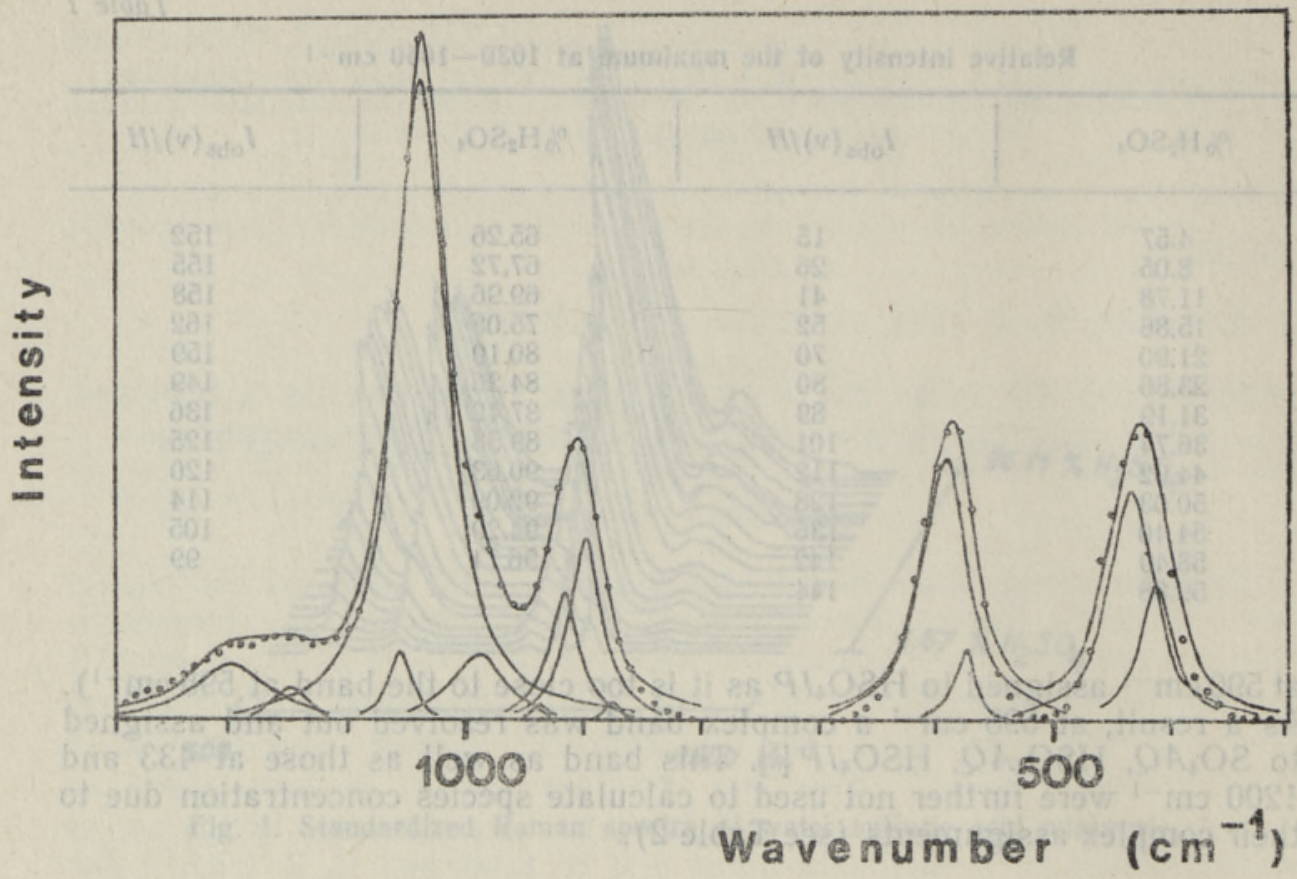

Pig. 2. Experimental spectrum points, resolution bands and calculated spectrum of $75.05 \%(\mathrm{w} / \mathrm{w})$ aqueous sulfuric acid solution.

Table 3

Areas of peaks $\left(A_{i}\right)$ in the Raman spectra of aqueous sulfuric acid solutions.

Region $1500-800 \mathrm{~cm}^{-1}$

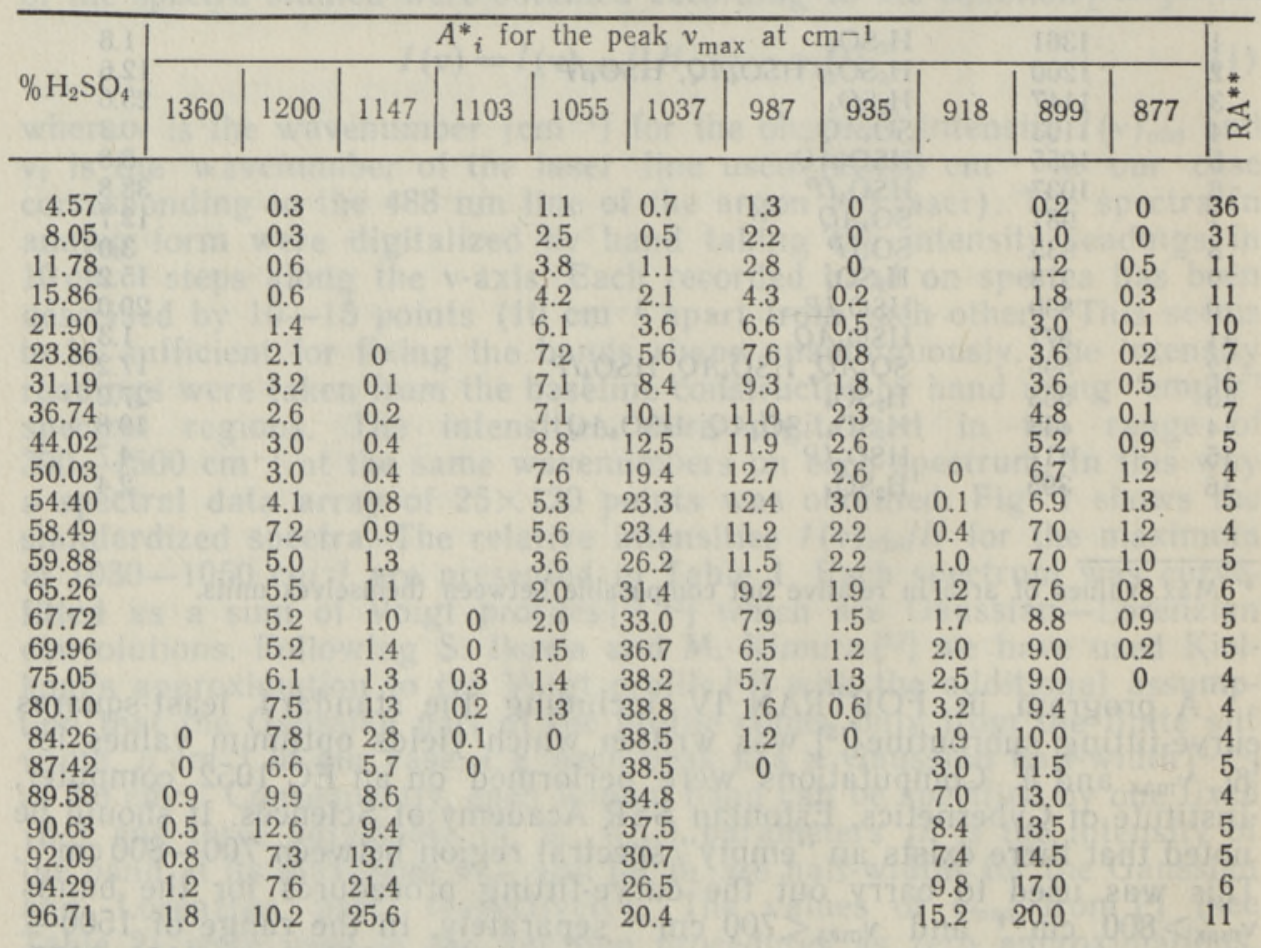

* The units used - see the subscribt to Table 2.

** Ratio RA (Eq. 2). 
five peaks (the respective maxima at $595,563,433,417,395 \mathrm{~cm}^{-1}$ ) were considered. The curve-fitting procedure was performed several times for each spectrum region using different initial values for $\beta_{\mathrm{L}}, v_{\max }$ and $h$ every time. The choice of the initial values for $\beta_{\mathrm{L}}$ and $h$ has a minor influence on band area: the relative scatter in band areas was $<10 \%$ of the respective mean value. The areas under the Voigt profiles were obtained by the trapezium method, using $2 \mathrm{~cm}^{-1}$ steps. The results of the curve-fitting procedure are presented in Tables 3 and 4 (see Fig. 2). The magnitude of the misfit was estimated by the ratio

$$
R A=100 \cdot A_{a, b}^{-1} \cdot \int_{a}^{b}\left|I(v)_{\mathrm{obs}}-I(v)_{\mathrm{calc}}\right| d v,
$$

where $A_{a, b}$ is the area under the standardized spectrum observed (Eq. 1) in the region $a \leqslant v \leqslant b$ and $I(v)_{\text {obs}, ~} \quad I(v)_{\text {calc }}$ are the observed (Eq. 1) and calculated intensity values at the wavenumber $v$, respectively. The $I(v)$ calc was obtained as a sum of band intensities at the $v$ considered. The values of $R A$ presented in Tables 3 and 4 demonstrate that the curve-fitting procedure yielded rather good results $(4 \% \leqslant R A \leqslant 15 \%)$.

The $v_{\max }$ values found depend on the stoichiometric acid concentration as shown in Fig. 3. Their values at the respective band area maximum are close to those given in Table 2. The dependence of $v_{\max }$ on the sulfuric acid stoichiometric concentration in the case of bands near 1050 and $980 \mathrm{~cm}^{-1}$ has also been found by S. Ikawa [12].

Table 4

Areas of peaks $\left(A_{i}\right)$ in the Raman spectra of aqueous sulfuric acid solutions. Region $300-700 \mathrm{~cm}^{-1}$

\begin{tabular}{|c|c|c|c|c|c|c|}
\hline \multirow[b]{2}{*}{$\% \mathrm{H}_{2} \mathrm{SO}_{4}$} & \multicolumn{5}{|c|}{$A^{*}{ }_{i}$ for the peak $v_{\max }$ at $\mathrm{cm}^{-1}$} & \multirow[b]{2}{*}{$R A^{* *}$} \\
\hline & 595 & 563 & 433 & 417 & 395 & \\
\hline 4.57 & 1.5 & & 1.4 & & & \\
\hline 8.05 & 1.9 & & 2.1 & & & 15 \\
\hline 11.78 & 2.7 & & 2.7 & & & 10 \\
\hline 15.86 & 3.9 & & 3.5 & & & 23 \\
\hline $\begin{array}{l}21.90 \\
23.86\end{array}$ & $\begin{array}{l}6.6 \\
7.1\end{array}$ & & $\begin{array}{l}5.7 \\
6.7\end{array}$ & & 12018 & $\begin{array}{l}18 \\
13\end{array}$ \\
\hline 31.19 & 8.0 & & 8.1 & 0.3 & & 10 \\
\hline 36.74 & 8.2 & & 9.5 & 0.2 & 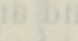 & 12 \\
\hline 44.02 & 9.4 & r & 11.5 & 0.2 & uat? & 20 \\
\hline 50.03 & 10.6 & & 10.2 & 2.0 & & 24 \\
\hline 54.40 & 14.5 & 0 & 13.1 & 1.6 & & 11 \\
\hline 58.49 & 17.2 & 0.2 & 19.8 & 1.2 & & 15 \\
\hline 59.88 & 15.0 & 0.2 & 19.0 & 1.5 & & 15 \\
\hline 65.26 & 16.6 & 0.6 & 17.0 & 2.5 & 0 & 15 \\
\hline 67.72 & 16.0 & 0.7 & 16.9 & 2.9 & 0.1 & 15 \\
\hline 69.96 & 15.6 & 0.6 & 12.5 & 3.2 & 0.1 & 25 \\
\hline 75.05 & 14.4 & 1.8 & 12.6 & 4.7 & 0.4 & 19 \\
\hline 80.10 & 13.6 & 3.0 & 11.8 & 4.2 & 0.6 & 16 \\
\hline $\begin{array}{l}84.26 \\
87.42\end{array}$ & 16.1 & 4.7 & 10.1 & 3.4 & 1.3 & 6 \\
\hline $\begin{array}{l}87.42 \\
89.58\end{array}$ & 13.0 & 7.0 & 9.7 & 2.8 & 1.4 & 15 \\
\hline $\begin{array}{l}89.58 \\
90.63\end{array}$ & $\begin{array}{r}10.8 \\
0.8\end{array}$ & 13.0 & 11.0 & 3.8 & 1.2 & 11 \\
\hline 92.09 & $\begin{array}{r}9.8 \\
10.2\end{array}$ & $\begin{array}{l}16.2 \\
19.8\end{array}$ & $\begin{array}{r}10.0 \\
9.6\end{array}$ & $\begin{array}{l}4.6 \\
3.4\end{array}$ & $\begin{array}{l}1.3 \\
1.5\end{array}$ & 11 \\
\hline 94.29 & 11.0 & 22.4 & 10.8 & 1.7 & 1.9 & 9 \\
\hline 96.71 & 9.7 & 27.2 & 10.6 & 2.5 & 2.4 & 10 \\
\hline
\end{tabular}

* The units used - see the subscribt to Table 2 .

** Ratio RA (Eq. 2). 


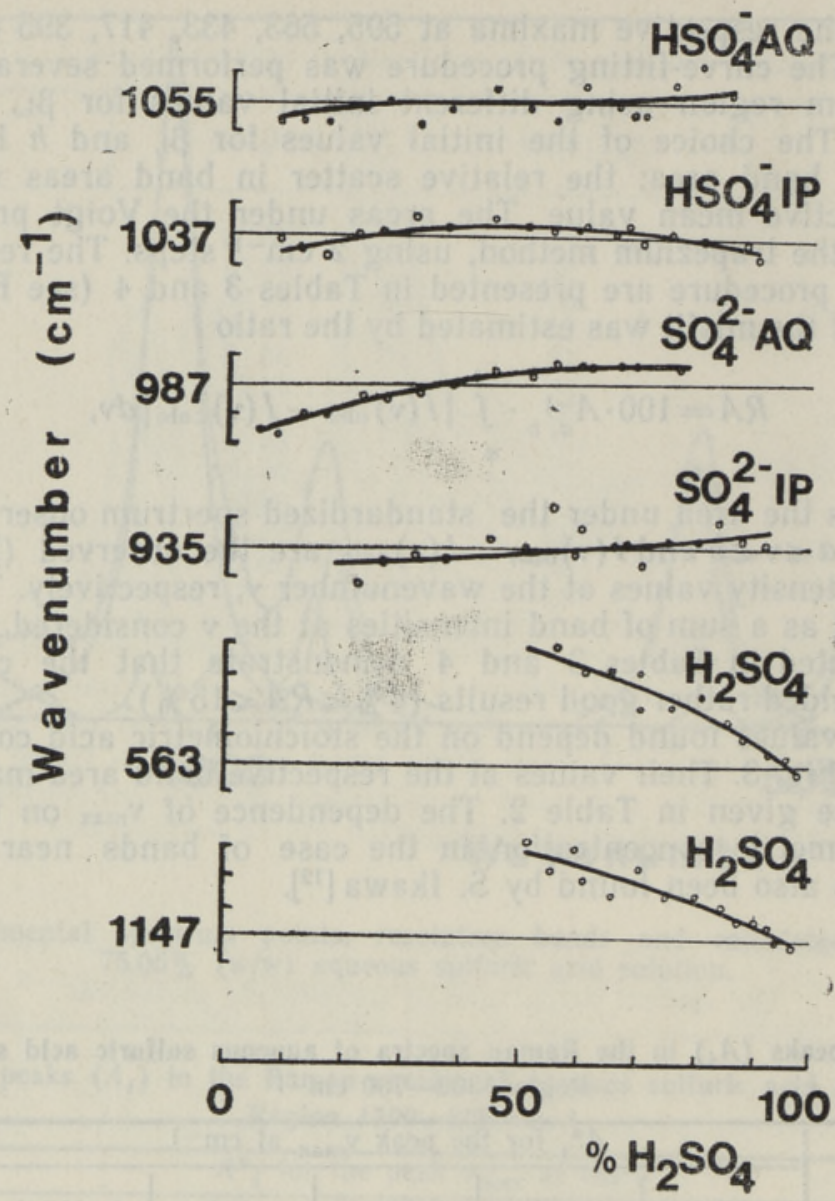

Fig. 3. Dependence of band maximum on stoichiometric acid concentration for the band used. On ordinate axes marks stand for every $5 \mathrm{~cm}^{-1}$.

\section{Species concentration in aqueous sulfuric acid mixtures}

Raman band area $A$ is related to the concentration of the species which generates the band through the equation in $\left[{ }^{10}\right]$

$$
A=J \cdot C \text {, }
$$

where $J$ is the specific or molar intensity of the band, and $C$ is the scattering species concentration in moles per liter. The areas of all the bands listed in Table 2 were plotted vs. $\% \mathrm{H}_{2} \mathrm{SO}_{4}$ (except the bands at 1200, 595 and $433 \mathrm{~cm}^{-1}$ for the reasons mentioned above; the bands at 1361 and $1103 \mathrm{~cm}^{-1}$ were also neglected because of their very small areas). For some bands, mostly rather weak ones at $395,918 \mathrm{~cm}^{-1}$ (both $\mathrm{H}_{2} \mathrm{SO}_{4}$ ), $877 \mathrm{~cm}^{-1}\left(\mathrm{HSO}_{4} A Q\right)$ and $417,899 \mathrm{~cm}^{-1} \quad\left(\mathrm{HSO}_{4} I P\right)$ the profiles $\mathrm{A}$ vs. $\%$ $\mathrm{H}_{2} \mathrm{SO}_{4}$ (w/w) exhibit quite a remarkable scatter. Therefore these bands were not used for the estimation of species concentrations. After making these exclusions the following bands remained for further treatment: $987 \mathrm{~cm}^{-1}\left(\mathrm{SO}_{4} A Q\right), 1055 \mathrm{~cm}^{-1}\left(\mathrm{HSO}_{4} A Q\right), 935 \mathrm{~cm}^{-1}\left(\mathrm{SO}_{4} I P\right), 1037 \mathrm{~cm}^{-1}$ $\left(\mathrm{HSO}_{4} I P\right.$ ), 563 and $1147 \mathrm{~cm}^{-1}$ (both for $\mathrm{H}_{2} \mathrm{SO}_{4}$ ). The areas of these bands were standardized according to

$$
B=A / A_{\max }
$$




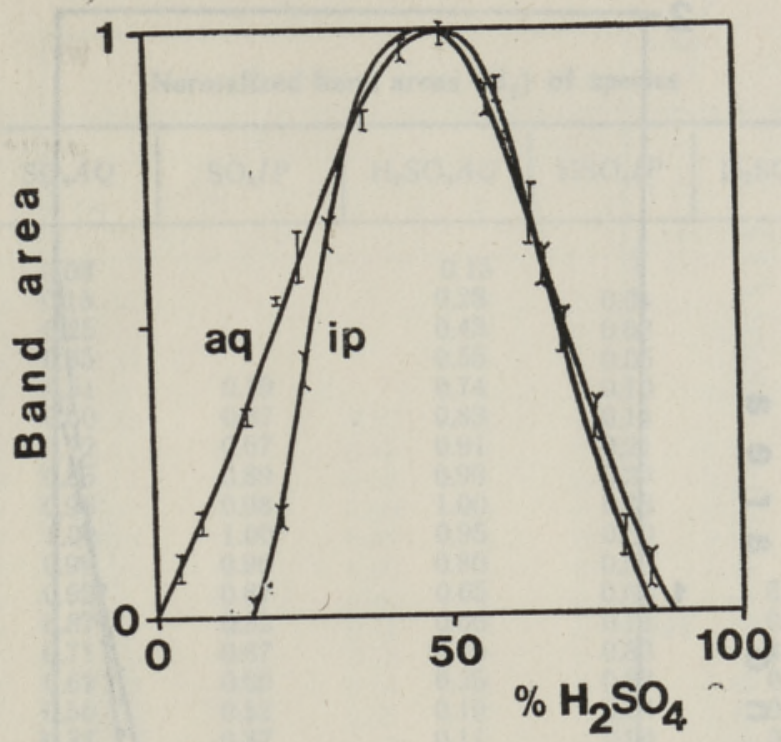

Fig. 4. Normalized areas of the bands specified to $\mathrm{SO}_{4} A Q$ and $\mathrm{SO}_{4} I P$ vs. $\%$ (w/w) $\mathrm{H}_{2} \mathrm{SO}_{4}$. Vertical bars represent uncertainties.

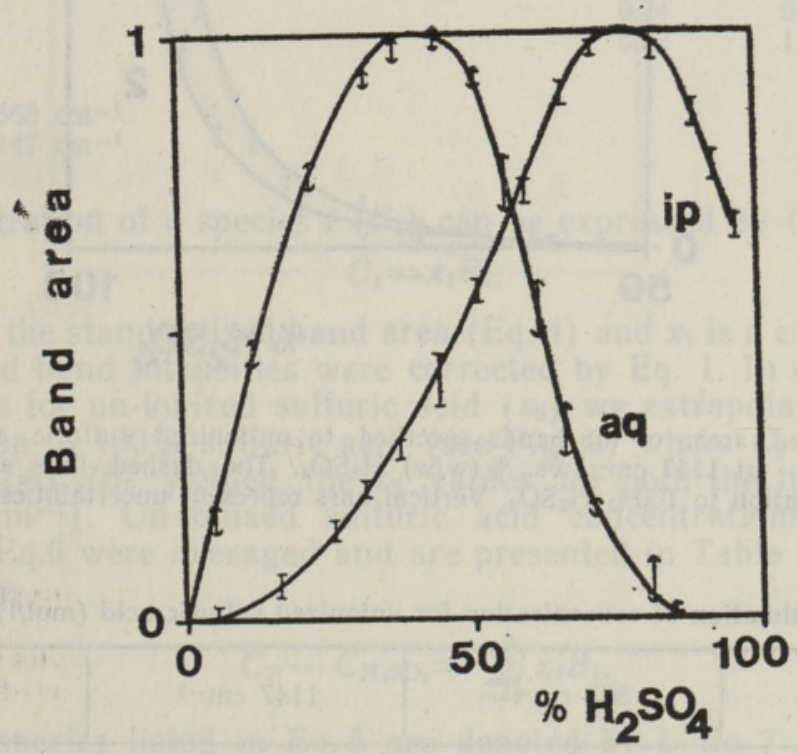

Fig. 5. Normalized areas of the bands specified to $\mathrm{HSO}_{4} A Q$ and $\mathrm{HSO}_{4} I P$ vs. $\%$ (w/w) $\mathrm{H}_{2} \mathrm{SO}_{4}$. Vertical bars represent uncertainties.

where $B$ is the normalized area of the band in the sulfuric acid solution considered, $A$ is the respective area in Table 3 or 4 and $A_{\max }$ is the maximum value of $A$ for the band studied (see Table 2). The normalization (Eq. 4) was used in order to give equal weights for all species in regression analysis. The respective examples are shown in Figs $4-6$. For a given aqueous sulfuric acid solution with a molar concentration $C_{T}$ we can write a balance equation

$$
C_{T}=C_{\mathrm{SO}_{4} A Q}+C_{\mathrm{SO}_{4} I P}+C_{\mathrm{HSO}_{4} A Q}+C_{\mathrm{HSO}_{4} I P}+C_{\mathrm{H}_{2} \mathrm{SO}_{4}}
$$




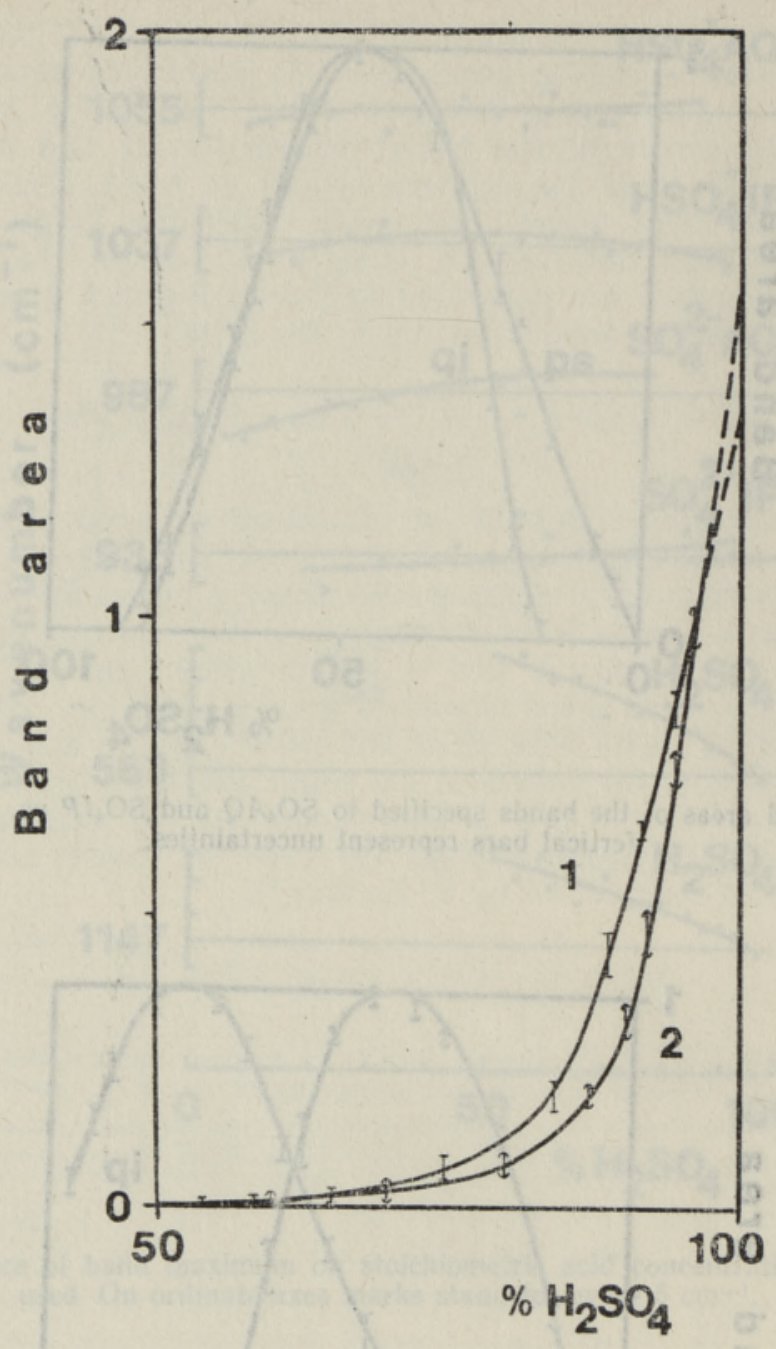

Fig. 6. Normalized areas of the bands specified to un-ionized sulfuric acid. $1-$ at $563 \mathrm{~cm}^{-1}$ and $2-$ at $1147 \mathrm{~cm}^{-1}$ vs. $\%(\mathrm{w} / \mathrm{w}) \mathrm{H}_{2} \mathrm{SO}_{4}$. The dashed lines show the extrapolation to $100 \% \mathrm{H}_{2} \mathrm{SO}_{4}$. Vertical bars represent uncertainties.

Table 5

Estimation of concentration for unionized sulfuric acid (mol/l)

\begin{tabular}{|c|c|c|c|}
\hline$\% \mathrm{H}_{2} \mathrm{SO}_{4}$ & $563 \mathrm{~cm}^{-1}$ & $1147 \mathrm{~cm}^{-1}$ & Average \\
\hline 54.40 & 0 & 96 & 0 \\
\hline 58.49 & 0.14 & 0.12 & 0.13 \\
\hline 59.88 & 0.14 & 0.12 & 0.13 \\
\hline 65.26 & 0.27 & 0.24 & 0.26 \\
\hline 67.72 & 0.41 & 0.24 & 0.33 \\
\hline 69.96 & 0.41 & 0.36 & 0.39 \\
\hline 75.05 & 0.82 & 0.48 & 0.65 \\
\hline 80.10 & 1.50 & 0.84 & 1.17 \\
\hline 84.26 & 2.60 & 1.56 & 2.08 \\
\hline 87.42 & 4.23 & 2.52 & 3.38 \\
\hline 89.58 & 7.10 & 3.60 & 5.35 \\
\hline 90.63 & 8.05 & 4.32 & 6.18 \\
\hline 92.09 & 9.42 & 5.40 & 7.41 \\
\hline 94.29 & 11.60 & 8.15 & 9.88 \\
\hline 96.71 & 13.65 & 12.00 & 12.83 \\
\hline
\end{tabular}


Normalized band areas $\left(B_{i}\right)$ of species

\begin{tabular}{|c|c|c|c|c|c|c|}
\hline$\% \mathrm{H}_{2} \mathrm{SO}_{4}$ & $\mathrm{SO}_{4} A Q$ & $\mathrm{SO}_{4} I P$ & $\mathrm{H}_{2} \mathrm{SO}_{4} A Q$ & $\mathrm{HSO}_{4} I P$ & $\mathrm{H}_{2} \mathrm{SO}_{4}{ }^{*}$ & $\mathrm{H}_{2} \mathrm{SO}_{4}{ }^{* * *}$ \\
\hline $\begin{array}{r}4.57 \\
8.05 \\
11.78 \\
15.86 \\
21.90 \\
25.86 \\
31.19 \\
36.74 \\
44.02 \\
50.03 \\
54.40 \\
58.49 \\
59.88 \\
65.26 \\
67.72 \\
69.96 \\
75.05 \\
80.10 \\
84.26 \\
87.42 \\
89.58 \\
90.63 \\
92.09 \\
94.29 \\
96.71\end{array}$ & $\begin{array}{l}0.08 \\
0.15 \\
0.25 \\
0.35 \\
0.51 \\
0.60 \\
0.72 \\
0.85 \\
0.96 \\
1.00 \\
0.99 \\
0.92 \\
0.87 \\
0.71 \\
0.62 \\
0.56 \\
0.37 \\
0.10\end{array}$ & $\begin{array}{l}0.19 \\
0.37 \\
0.67 \\
0.89 \\
0.98 \\
1.00 \\
0.96 \\
0.87 \\
0.82 \\
0.67 \\
0.59 \\
0.52 \\
0.37 \\
0.22\end{array}$ & $\begin{array}{l}0.15 \\
0.28 \\
0.43 \\
0.55 \\
0.74 \\
0.83 \\
0.91 \\
0.99 \\
1.00 \\
0.95 \\
0.80 \\
0.65 \\
0.56 \\
0.35 \\
0.25 \\
0.19 \\
0.11 \\
0.04\end{array}$ & $\begin{array}{l}0.01 \\
0.03 \\
0.05 \\
0.10 \\
0.14 \\
0.21 \\
0.29 \\
0.38 \\
0.50 \\
0.58 \\
0.68 \\
0.71 \\
0.83 \\
0.88 \\
0.94 \\
0.99 \\
1.00 \\
0.97 \\
0.92 \\
0.85 \\
0.83 \\
0.79 \\
0.74 \\
0.62\end{array}$ & $\begin{array}{l} \\
\\
\\
\\
\\
\\
\\
\\
0.01 \\
0.01 \\
0.02 \\
0.03 \\
0.03 \\
0.06 \\
0.11 \\
0.19 \\
0.31 \\
0.52 \\
0.59 \\
0.69 \\
0.85 \\
1.00\end{array}$ & $\begin{array}{l}0.01 \\
0.01 \\
0.02 \\
0.02 \\
0.03 \\
0.04 \\
0.07 \\
0.13 \\
0.21 \\
0.30 \\
0.36 \\
0.45 \\
0.68 \\
1.00\end{array}$ \\
\hline
\end{tabular}

* Peak at $563 \mathrm{~cm}^{-1}$.

** Peak at $1147 \mathrm{~cm}^{-1}$.

The concentration of a species $i\left(C_{i}\right)$ can be expressed by (see also Eq. 3)

$$
C_{i}=x_{i} B_{i} \text {, }
$$

where $B_{i}$ is the standardized band area (Eq. 4) and $x_{i}$ is a constant because the observed band intensities were corrected by Eq. 1. In order to obtain the $x_{i}$ value for un-ionized sulfuric acid $\left(x_{5}\right)$ we extrapolated the plot $B_{5}$ vs. $\%$ acid up to $100 \%$ sulfuric acid (see Fig. 6 ) where $C_{5}=18,61 \mathrm{~mole} / \mathrm{L}$. The ratio $x_{5}=C_{5} / B_{5}$ yielded the $x_{5}$ values for both the lines used (563 and $\left.1147 \mathrm{~cm}^{-1}\right)$. Un-ionized sulfuric acid concentrations $\left(C_{\mathrm{H}_{2} \mathrm{SO}_{4}}\right)$ calculated by Eq.6 were averaged and are presented in Table 5. This enables us to obtain

$$
C_{T}-C_{\mathrm{H}_{2} \mathrm{SO}_{4}}=\sum_{i=1}^{4} x_{i} B_{i}
$$

where the species listed in Eq. 5 are denoted by $i$. Eq. 7 can be written for each of the 25 sulfuric acid solutions. This yields a set of 25 equations with 4 unknown coefficients $\left(x_{1}, \ldots, x_{4}\right)$. Using the $B_{i}$ values from Table 6 the following regression coefficients were obtained: $\mathrm{SO}_{4} A Q$, $x_{1}=-1.75 \pm 4.44, \mathrm{SO}_{4} I P, \quad x_{2}=-0.29 \pm 3.23, \mathrm{HSO}_{4} A Q, x_{3}=3.07 \pm 2.23$ and $\mathrm{HSO}_{4} I P, x_{4}=12.60 \pm 0.66$ (the respective standard deviations at $f=20$ are also presented). The negative values of $x_{1}$ and $x_{2}$ are meaningless and $x_{3}$ is rather uncertain. This result is not unexpected because the scales $B_{1}, B_{2}$ and $B_{3}$ are strongly correlated among themselves: $R_{1,2}=0.946, R_{1,3}=0.744$ and $R_{2,3}=0.595$. The $R_{1,2}$ value implies that there is no possibility of differentiating $\mathrm{SO}_{4} A Q$ and $\mathrm{SO}_{4} I P$ concentrations. In this situation the use of the equation

$$
C_{T}-C_{\mathrm{H}_{2} \mathrm{SO}_{4}}-C_{\mathrm{SO}_{4}^{2-}}=x_{3} B_{3}+x_{4} B_{4}
$$




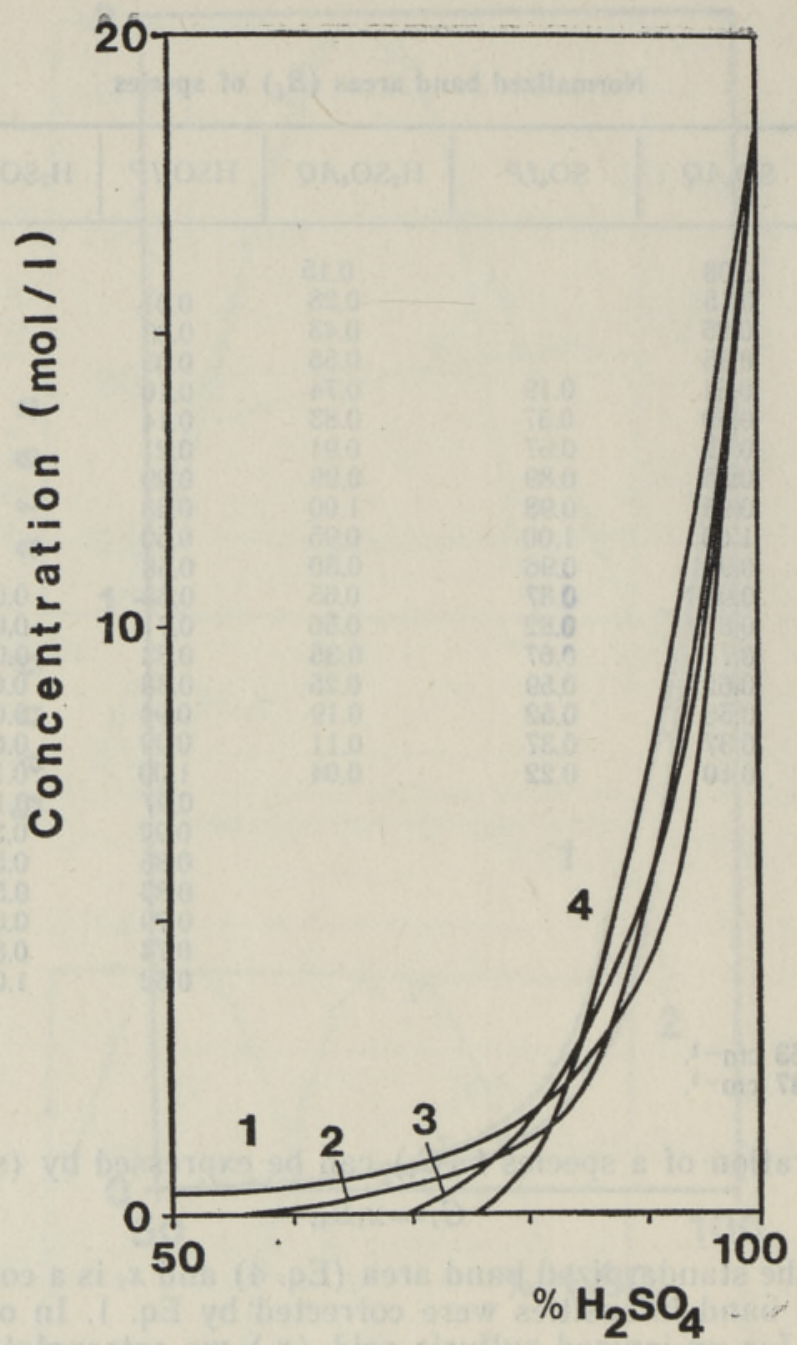

Fig. 7. Comparison of un-ionized sulfuric acid concentrations vs. $\%(w / w) ~ \mathrm{H}_{2} \mathrm{SO}_{4}$ estimated by different authors. $1-$ from $\left[{ }^{5}\right], 2-$ present study, $3-$ from $\left.{ }^{3}\right]$ and $4-$ from $\left[{ }^{2}\right]$.

is probably best we could do (where $C_{\mathrm{SO}_{4}^{2-}}$ is the total $\mathrm{SO}_{4}^{2-}$ concentration estimated by N. B. Librovich $\left.{ }^{2}\right]$ or $\mathrm{H}$. Chen [']; see Fig. 8 ). Eq. 8 was applied to the data of 17 solutions (covering the range of $4.57-75.05 \%$ $\mathrm{H}_{2} \mathrm{SO}_{4}$ ). Using the $C_{\mathrm{SO}_{4}^{2-}}$ values of N. B. Librovich [ $\left.{ }^{2}\right]$ we obtained $x_{3}=0.86 \pm 0.35$ and $x_{4}=11.06 \pm 0.41$. The respective results with $H$. Chen's data ['] were $x_{3}=0.71 \pm 0.39$ and $x_{4}=10.07 \pm 0.46$. Assuming that the $C_{\mathrm{SO}_{4}^{2-}}$ values found by N. B. Librovich $\left.{ }^{2}\right]$ and $H$. Chen $\left[{ }^{1}\right]$ are probably the sum $C_{\mathrm{SO}_{\star} A Q}+C_{\mathrm{SO}, I P}$ we used the equation

$$
C_{\mathrm{SO}_{4}^{2-}}=x_{1} B_{1}+x_{2} B_{2}
$$

to obtain $x_{1}$ and $x_{2}$. If $C_{\mathrm{SO}_{4}^{2-}}$ was taken from [ $\left.{ }^{2}\right], x_{1}=0.92 \pm 0.18, x_{2}=$ $0.12 \pm 0.19$ and respectively, the data of $H$. Chen ['] yielded $x_{1}=1.02 \pm 0.94$ and $x_{2}=0.90 \pm 1.00$.

The concentration profiles of $\mathrm{SO}_{4} A Q, \mathrm{SO}_{4} I P, \mathrm{HSO}_{4} A Q, \mathrm{HSO}_{4} I P$ and $\mathrm{H}_{2} \mathrm{SO}_{4}$ estimated in this paper (Eq. 6) are presented in Table 7. A comparison of the data from Table 7 with the respective earlier ones (see 
Table 7

Concentrations of species (mol/l)

\begin{tabular}{|c|c|c|c|c|c|c|c|c|c|}
\hline \multirow[b]{2}{*}{$C_{T}$} & \multicolumn{2}{|c|}{$\mathrm{SO}_{4} A Q$} & \multicolumn{2}{|c|}{$\mathrm{SO}_{4} I P$} & \multicolumn{2}{|c|}{$\mathrm{HSO}_{4} A Q$} & \multicolumn{2}{|c|}{$\mathrm{HSO}_{4} I P$} & \multirow[b]{2}{*}{$\mathrm{H}_{2} \mathrm{SO}_{4}$} \\
\hline & {$\left[{ }^{2}\right]$} & {$\left[{ }^{1}\right]$} & {$\left[{ }^{2}\right]$} & {$\left[{ }^{1}\right]$} & 2 & 1 & 2 & 1 & \\
\hline 0.478 & 0.07 & 0.08 & & & 0.13 & 0.11 & & & \\
\hline 0.862 & 0.14 & 0.15 & & & 0.24 & 0.20 & 0.11 & 0.10 & \\
\hline 1.291 & 0.23 & 0.25 & & & 0.37 & 0.30 & 0.33 & 0.30 & \\
\hline 1.788 & 0.32 & 0.36 & & & 0.47 & 0.39 & 0.55 & 0.50 & \\
\hline 2.571 & 0.47 & 0.52 & 0.02 & 0.17 & 0.64 & 0.52 & 1.11 & 1.01 & \\
\hline 3.116 & 0.55 & 0.61 & 0.05 & 0.33 & 0.72 & 0.59 & 1.55 & 1.41 & \\
\hline 3.896 & 0.66 & 0.73 & 0.08 & 0.60 & 0.78 & 0.64 & 2.32 & 2.12 & \\
\hline 4.761 & 0.78 & 0.87 & 0.11 & 0.80 & 0.85 & 0.70 & 3.21 & 2.92 & \\
\hline 5.991 & 0.88 & 0.98 & 0.12 & 0.88 & 0.86 & 0.71 & 4.20 & 3.83 & \\
\hline 7.098 & 0.92 & 1.02 & 0.12 & 0.90 & 0.82 & 0.67 & 5.53 & 5.04 & \\
\hline 7.958 & 0.91 & 1.01 & 0.12 & 0.86 & 0.69 & 0.57 & 6.41 & 5.84 & \\
\hline 8.813 & 0.84 & 0.94 & 0.11 & 0.78 & 0.56 & 0.46 & 7.52 & 6.85 & 0.13 \\
\hline 9.114 & 0.80 & 0.89 & 0.10 & 0.73 & 0.48 & 0.40 & 7.85 & 7.15 & 0.13 \\
\hline 10.32 & 0.65 & 0.72 & 0.08 & 0.60 & 0.30 & 0.25 & 9.18 & 8.36 & 0.26 \\
\hline 10.91 & 0.57 & 0.63 & 0.07 & 0.53 & 0.22 & 0.18 & 9.73 & 8.86 & 0.33 \\
\hline 11.45 & 0.51 & 0.57 & 0.06 & 0.47 & 0.16 & 0.13 & 10.40 & 9.47 & 0.39 \\
\hline 12.74 & 0.34 & 0.38 & 0.05 & 0.33 & 0.09 & 0.08 & 10.95 & 9.97 & 0.65 \\
\hline 14.07 & 0.09 & 0.10 & 0.03 & 0.20 & & & 11.06 & 10.07 & 1.17 \\
\hline $\begin{array}{l}15.17 \\
15.93\end{array}$ & & & & & & & $\begin{array}{c}10.70 \\
10.20\end{array}$ & $\begin{array}{c}9.77 \\
9.26\end{array}$ & $\begin{array}{l}2.08 \\
3.38\end{array}$ \\
\hline 16.50 & & & & & & & 9.40 & 8.56 & 5.35 \\
\hline 16.75 & & & & & & & 9.15 & 8.36 & 6.18 \\
\hline $\begin{array}{l}17.08 \\
17.56\end{array}$ & & & & & & & 8.74 & 7.96 & $\begin{array}{l}7.41 \\
0.88\end{array}$ \\
\hline $\begin{array}{l}17.56 \\
18.05\end{array}$ & & & & & & & $\begin{array}{l}8.20 \\
6.85\end{array}$ & $\begin{array}{l}7.45 \\
6.21\end{array}$ & $\begin{array}{r}9.88 \\
12.83\end{array}$ \\
\hline
\end{tabular}

1 - concentration of $\mathrm{SO}_{4}^{2-}$ is from [ $\left.{ }^{1}\right]$.

2 - concentration of $\mathrm{SO}_{4}^{2-}$ is from $\left[{ }^{2}\right]$.

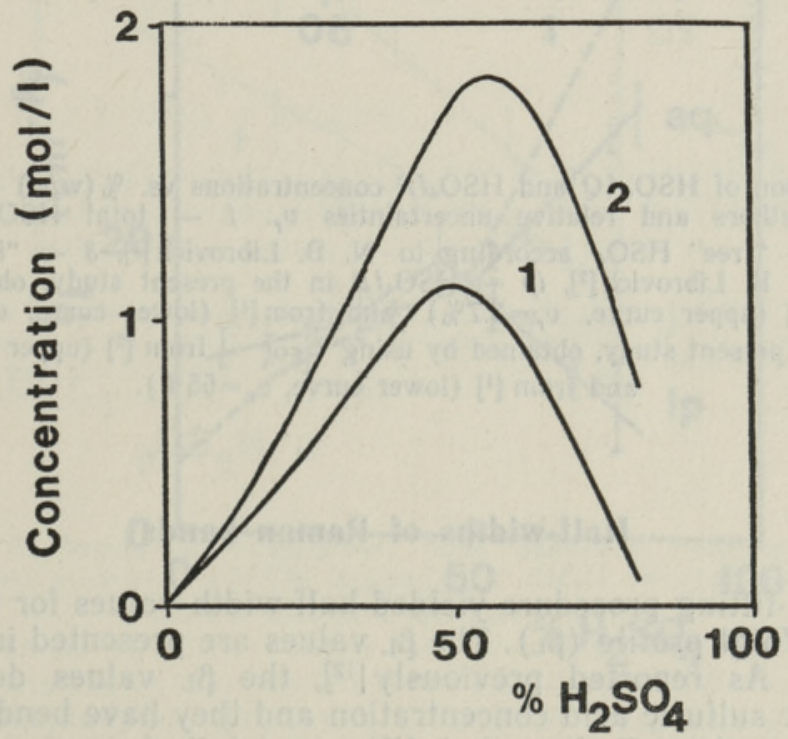

Fig. 8. Comparison of $\mathrm{SO}_{4}{ }^{2-}$ concentrations vs. $\%$ (w/w) $\mathrm{H}_{2} \mathrm{SO}_{4}$ estimated by different authors. $1-$ from $\left.{ }^{2}\right], 2-$ from $\left[{ }^{1}\right]$. 
Figs 7 and 9) leads to the following conclusions. First, the mean concentration profile for un-ionized sulfuric acid (see Fig. 7) agrees rather well with the earlier estimates $[2,3,5]$. Second, the results of $\mathrm{H}$. Chen and D. E. Irish ['] are purely based on the relative integrated intensity of the band at $981 \mathrm{~cm}^{-1}$ assigned to the sulfate ion. Their $C_{\mathrm{HSO}_{4}^{-}}=C_{T}-C_{\mathrm{SO}_{4}^{-2}}$. Therefore, disagreement with these concentration profiles [ $\left.{ }^{1]}\right]$ is not surprising. Third, the study of N. B. Librovich $\left[{ }^{2}\right]$ is based on the unresolved bands and the concentration of $\mathrm{HSO}_{4} I P$ has been calculated as a difference $C_{T}-\left(C_{\mathrm{H}_{2} \mathrm{SO}_{4}}+C_{\mathrm{HSO}_{4}^{-}}+C_{\mathrm{SO}_{4}^{2}}\right)$. This results in large disagreement between species concentration profiles of his paper $\left.{ }^{2}\right]$ and those of the present study (see Fig. 9).

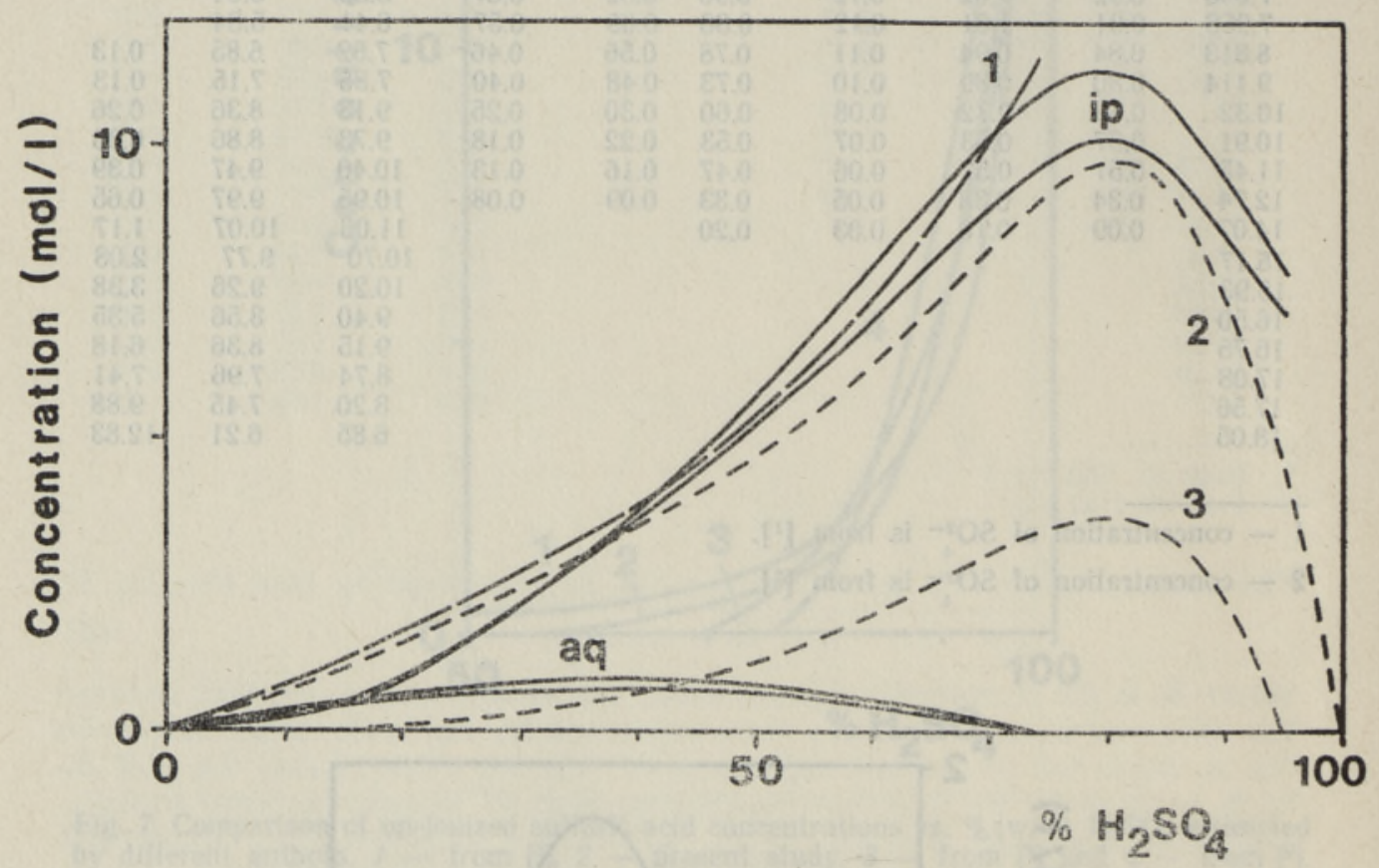

Fig. 9. Comparison of $\mathrm{HSO}_{4} A Q$ and $\mathrm{HSO}_{4} I P$ concentrations vs. $\%$ (w/w) $\mathrm{H}_{2} \mathrm{SO}_{4}$ estimated by different authors and relative uncertainties $v_{r} 1$ - total $\mathrm{HSO}_{4}$, estimated by H. Chen [ ${ }^{1}$ ], $2-$ "free" $\mathrm{HSO}_{4}$ according to N. B. Librovich $\left.{ }^{2}\right], 3$ - "ionpaired" $\mathrm{HSO}_{4}$ according to N. B. Librovich [2], ip - $\mathrm{HSO}_{4} I P$ in the present study, obtained by using $C_{\mathrm{So}^{2-}}$ from [ $\left.{ }^{2}\right]$ (upper curve, $v_{r}=3.7 \%$ ) and from ['] (lower curve, $v_{r}=4.6 \%$ ), $a q-$ $\mathrm{HSO}_{4} A Q$ in the present study, obtained by using $\mathrm{C}_{\mathrm{SO}^{2-}}$ from [ $\left.{ }^{2}\right]$ (upper curve, $v_{r}=40 \%$ ) and from ['] (lower curve, $v_{r}=55 \%$ ).

\section{Half-widths of Raman bands}

The curve-fitting procedure yielded half-width values for the Lorenzian part of the Voigt profile $\left(\beta_{\mathrm{L}}\right)$. The $\beta_{\mathrm{L}}$ values are presented in Table 8 and Figs $10-12$. As reported previously $\left[{ }^{12}\right]$, the $\beta_{\mathrm{L}}$ values depend on the stoichiometric sulfuric acid concentration and they have bends. In general, our data assure these findings but differ in details from those of S. Ikawa and $M$. Kimura [ $\left.{ }^{12}\right]$; see Figs 10 and 11 . It should be pointed out that in two cases (for bands at 935 and $1055 \mathrm{~cm}^{-1}$ ) our $\beta_{\mathrm{L}}$ values have maxima 
Half-widths of Lorenzian component in Raman spectra $\left(\mathrm{cm}^{-1}\right)$

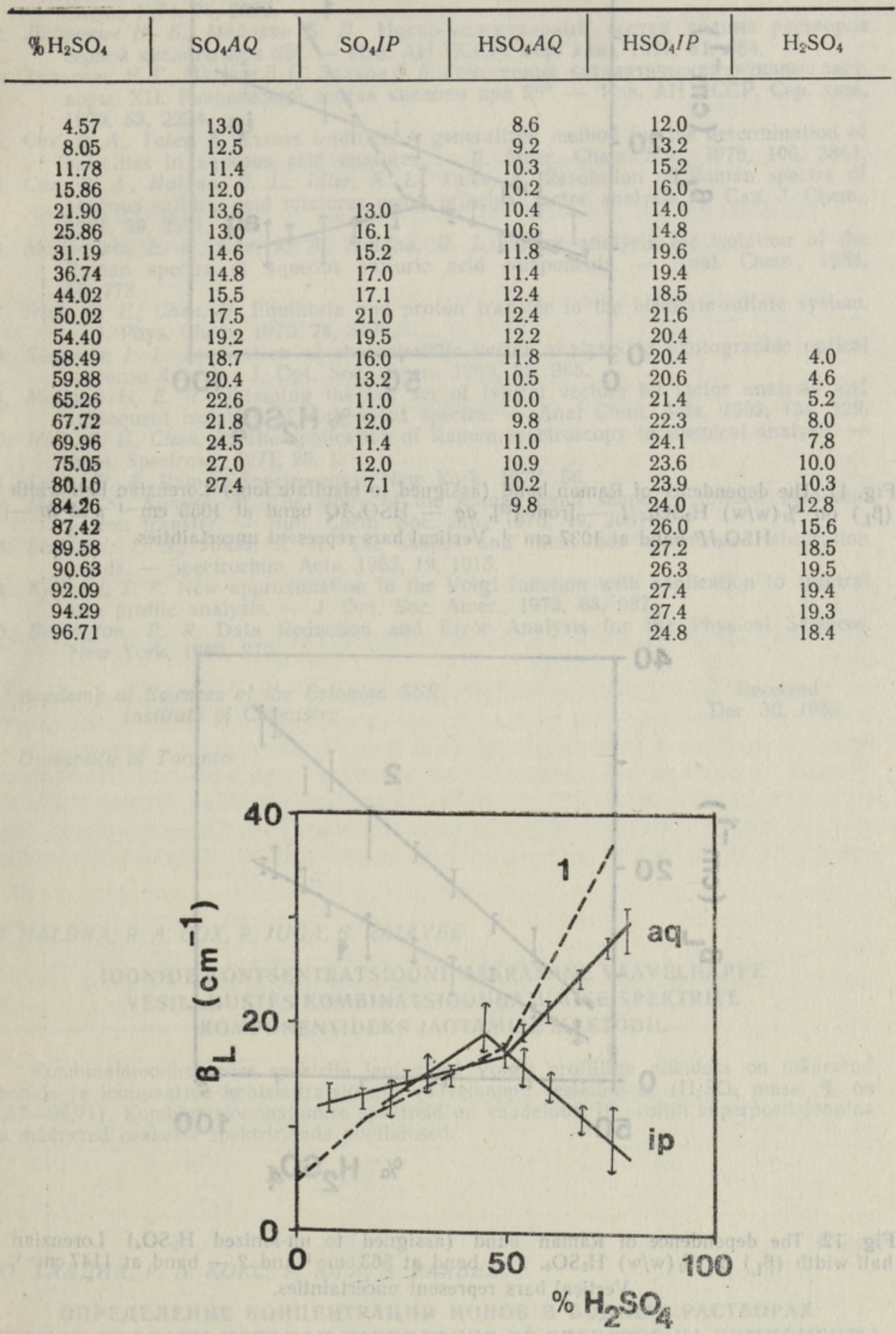

Fig. 10. The dependence of Raman band (assigned to sulfate ions) Lorenzian half-width $\left(\beta_{\mathrm{L}}\right)$ on $\%(\mathrm{w} / \mathrm{w}) \mathrm{H}_{2} \mathrm{SO}_{4} .1-$ from $\left[{ }^{12}\right], a q-\mathrm{SO}_{4} A Q$ band at $987 \mathrm{~cm}^{-1}$ and $i p-\mathrm{SO}_{4} I P$ band at $935 \mathrm{~cm}^{-1}$. Vertical bars represent uncertainties. 


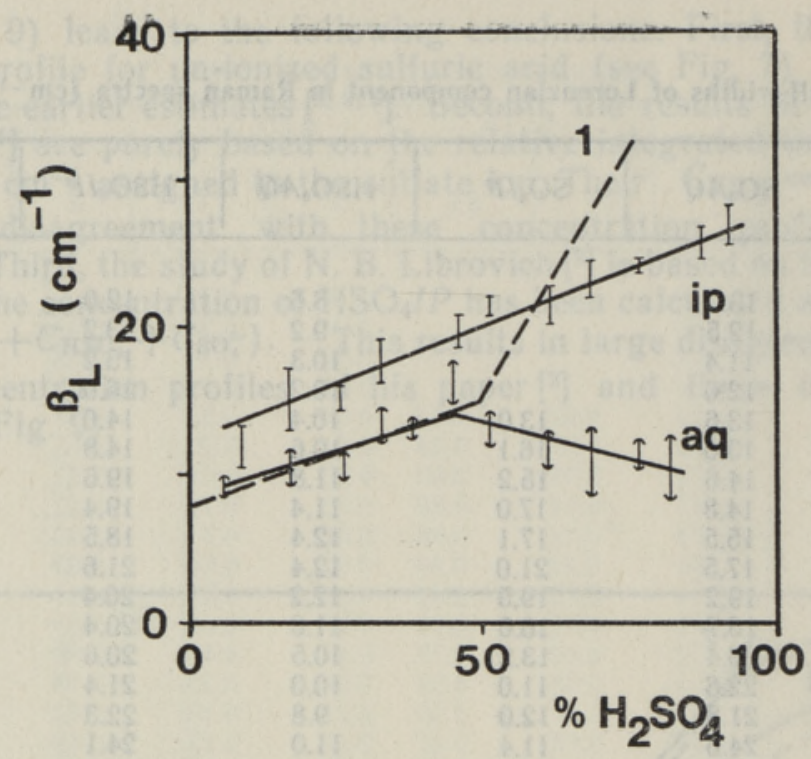

Fig. 11. The dependence of Raman band (assigned to bisulfate ions) Lorenzian half-width $\left(\beta_{\mathrm{L}}\right)$ on $\%(\mathrm{w} / \mathrm{w}) \mathrm{H}_{2} \mathrm{SO}_{4} .1-$ from $\left[{ }^{12}\right]$, aq $-\mathrm{HSO}_{4} A Q$ band at $1055 \mathrm{~cm}^{-1}$ and ip $\mathrm{HSO}_{4} I P$ band at $1037 \mathrm{~cm}^{-1}$. Vertical bars represent uncertainties.

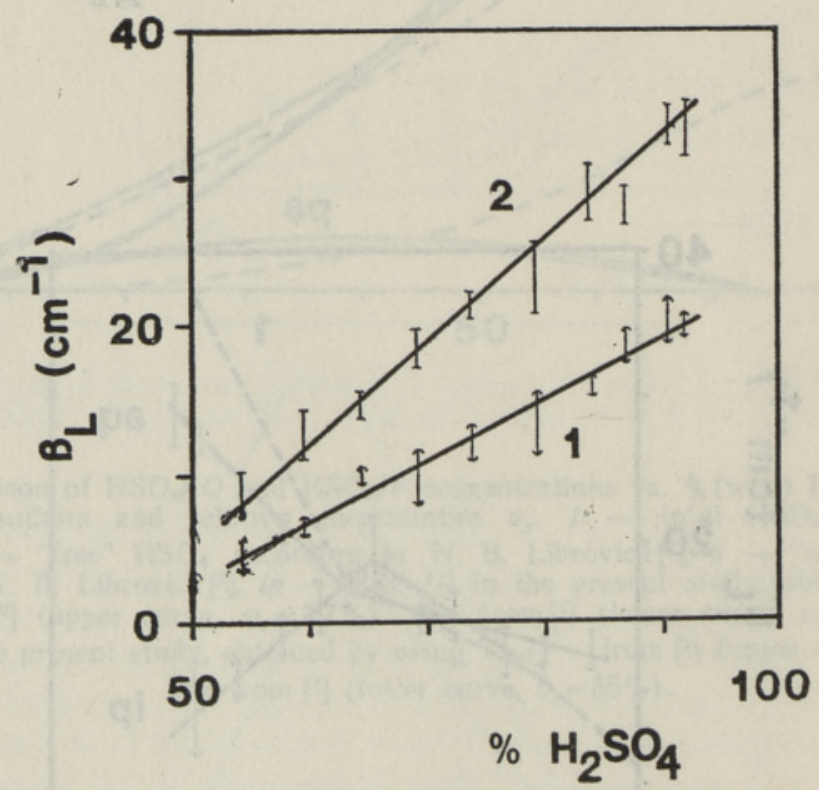

Fig. 12. The dependence of Raman band (assigned to un-ionized $\mathrm{H}_{2} \mathrm{SO}_{4}$ ) Lorenzian half-width $\left(\beta_{\mathrm{L}}\right)$ on $\%$ (w/w) $\mathrm{H}_{2} \mathrm{SO}_{4} .1$ - band at $563 \mathrm{~cm}^{-1}$ and $2-$ band at $1147 \mathrm{~cm}^{-1}$. Vertical bars represent uncertainties.

at $45 \% \mathrm{H}_{2} \mathrm{SO}_{4}$ and bend down with increasing stoichiometric concentration. This indicates that the mean spectroscopic lifetimes of respective species $\left(\mathrm{SO}_{4} I P\right.$ and $\left.\mathrm{HSO}_{4} A Q\right)$ pass through a minimum and increase if the stoichiometric acid concentration exceeds $45 \%$. 


\section{REFERENCES}

1. Chen, H., Irish, D. E. A Raman spectral study of bisulfate sulfate system. II. Constitution, equilibria, and ultrafast proton transfer in sulfuric acid. - J. Phys. Chem., 1971, 75, 2072.

2. Либрович Н. Б., Майоров В. Д. Ионно-молекулярный состав водных растворов серной кислоты при $25^{\circ}$. - Изв. АН СССР. Сер. хим., 1977, 51, 684.

3. Зарахани Н.Г., Маркин В.С., Залков Г. Е. Гомогенные каталитические активные растворы. ХІІ. Равновесный состав кислоты при $25^{\circ}$. - Изв. АН СССР. Сер. хим., 1979, 53, 2294.

4. Cox, R. A., Yates, $K$. Excess acidities. A generalized method for the determination of basicities in aqueous acid mixtures. - J. Amer. Chem. Soc., 1978, 100, 3861.

5. Cox, R. A., Haldna, U. L., Idler, K. L., Yates, K. Resolution of Raman spectra of aqueous sulfuric acid mixtures using principal factor analysis. - Can. J. Chem., 1981, 59, 2591.

6. Malinouski, E. R., Cox, R. A., Haldna, U. L. Factor analysis for isolation of the Raman spectra of aqueous sulfuric acid components. - Anal. Chem., 1984, 56, 778 .

7. Irish, D. E., Chen, H. Equilibria and proton transfer in the bisulfate-sulfate system.

- J. Phys. Chem., 1970, 74, 3796.

8. Simonds, J. L. Application of characteristic vector analysis to photographic optical response data. - J. Opt. Soc. Amer., 1963, 53, 968.

9. Malinowski, E. R. Obtaining the key set of typical vectors by factor analysis and subsequent isolation of component spectra. - Anal Chim. Acta, 1982, 134, 129.

10. Irish, D. E., Chen, $H$. The application of Raman spectroscopy to chemical analysis. Appl. Spectrosc., 1971, 25, 1.

11. Long, D. A. Raman Spectroscopy. New York, 1977, 56.

12. Ikawa, S., Kimura, M. The study of the Raman band shape of sulfuric acid and proton transfer. - Bull. Chem. Soc. Jap., 1976, 49, 2051.

13. Seshadri, J. S., Jones, R. N. The shapes and intensities of infrared absorption bands. - Spectrochim. Acta, 1963, 19, 1013.

14. Kielkopf, J. F. New approximation to the Voigt function with application to spectral line profile analysis. - J. Opt. Soc. Amer., 1973, 63, 987.

15. Bevington, $P . R$. Data Reduction and Error Analysis for the Physical Sciences. New York, 1969, 272.

Academy of Sciences of the Estonian SSR, Institute of Chemistry

University of Toronto

O. HALDNA, R. A. COX, R. JUGA, E. RAJAVEE

\section{IOONIDE KONTSENTRATSIOONI MÄARRAMINE VÄÄVELHAPPE VESILAHUSTES KOMBINATSIOONHAJUMISE SPEKTRITE KOMPONENTIDEKS JAOTAMISE MEETODIL}

Kombinatsioonhajumise spektrite jaotamisel Voigti profiiliga piikideks on määratud ioonide ja ioonpaaride kontsentratsioonid väävelhappe vesilahustes $\left(\mathrm{H}_{2} \mathrm{SO}_{4}\right.$ massi $\%$ on $4,57-96,71)$. Kombinatsioonhajumise spektreid on vaadeldud 16 profiili superpositsioonina ja määratud osakeste spektriribade poollaiused.

Ю. ХАЛДНА, Р. А. КОКС, Р. ЮГА, Э. РАЯВЕЕ

\section{ОПРЕДЕЛЕНИЕ КОНЦЕНТРАЦИИ ИОНОВ В ВОДНЫХ РАСТВОРАХ СЕРНОИ КИСЛОТЫ МЕТОДОМ РАЗДЕЛЕНИЯ КР-СПЕКТРОВ НА КОМПОНЕНТЫ}

Путем разделения КР-спектров на профили Фойгта определены конщентрацин ионов и ионных пар в водных растворах серной кислоты в интервале $4,57-96,71 \%$ мас. $\mathrm{H}_{2} \mathrm{SO}_{4}$. КР-спектры рассмотрены в суперпозиции 16 отдельных полос. Для частиц определены значения ширин полос на полувысоте. 